\title{
Improving adherence to insulin: Hope with degludec
}

\author{
Sanjay Kalra, AG Unnikrishnan ${ }^{1}$, AK Das ${ }^{2}$ \\ Department of Endocrinologist, Bharti Hospital and B.R.I.D.E., Karnal, Haryana, ${ }^{1} \mathrm{CEO}$ and Endocrinologist, Chellaram Diabetes Institute, \\ Pune, Maharashtra, ${ }^{2}$ Medical Superintendent and Senior Professor, Jawaharlal Institute of Postgraduate Medical Education and Research, \\ Puducherry, India
}

Scientific literature on diabetes supports the contention that research in diabetes is increasing, which we understand more about its pathophysiology, ${ }^{[1]}$ and that we have better drugs to manage it. These improvements, however, do not seems to be able to keep pace with the needs imposed by the diabetes pandemic. For every new therapeutic target unearthed and for every new drug discovered, diabetes poses a fresh challenge. For example, the discovery of insulin brought succor to many sufferers, yet insulin-related challenges like compliance, hypoglycemia, and weight gain continue to vex clinicians and their patients.

Because of these bitter truths, the average glycated hemoglobin (HbA1c) levels of Indian patients show no sign of improving. Observational studies of diabetes therapies performed in India have returned consistently good results over the past two decades. ${ }^{[2,3]}$ An optimist may take this as proof that clinicians have succeeded in preventing the epidemic from worsening its impact, in spite of a much greater patient load being handled. A more accurate assessment, however, would be that we have not done enough to stem the tide of diabetes.

It is of course easy to pin the blame on basic science and pharmacology for the limitations of current therapy. For example, one might state that currently developed therapeutic tools intrude into our patients' lifestyles, thus limiting their acceptance. They may also have a negative impact on the quality of the person with diabetes. However, what is more probable is that the advances in

\begin{tabular}{|l|l|}
\hline \multicolumn{2}{|c|}{ Access this article online } \\
\hline Quick Response Code: & Website: \\
\hline & www.josh.net \\
\hline & \\
\hline & \\
\hline
\end{tabular}

diagnostics and therapeutics do not get translated to clinical practice. It is important that clinicians talk to basic scientists, and a cross-exchange of clinician needs and therapeutic ideas are needed to usher in a paradigm change in diabetes management. Only then would the bench-to-bedside translation become a reality in clinical diabetology.

Diabetes prevalence is linked to socio-economic change, and it is also true that the success of its management is dependent on social realities. Here are few examples - the elderly widow who is afraid of pricking herself, but does not mind an injection from the nurse; the busy house wife who just cannot remember to take her injections half an hour before meals; and the dapper executive who needs a sleek pen to go along with his branded attire. All these are real people with diabetes, with differing social needs, with differing definitions of a patient-friendly insulin or delivery device.

In such a scenario, the diabetes care professional usually individualizes insulin therapy according to the patient's need, so as to optimize adherence [Table 1].

While the choice of an injection preparation delivery device and insulin regime (basal vs premixed vs intensive) is often influenced by clinical factors, psychological and social factors play an important role in the shared decisionmaking process. ${ }^{[4]}$ Patients prefer insulin and delivery devices with the attributes listed in Table 2.

In fact the limiting factor in diabetes therapeutics is often adherence, rather than appropriate prescription of therapy. Current diabetology is evolving at a fast pace. A clear shift toward patient comfort, as well as provider convenience, is visible in therapeutic development: The popularity of fixed dose combination (FDCs) in diabetes and hypertension is a reflection of this trend. ${ }^{[5]}$ Another pointer in this direction is the use of modern oral glucose- 


\begin{tabular}{|c|c|}
\hline $\begin{array}{l}\text { Product (drug) } \\
\text { Pen (device) } \\
\text { Physician } \\
\text { Patient } \\
\text { Public (comm }\end{array}$ & \\
\hline \multicolumn{2}{|c|}{$\begin{array}{l}\text { Table 2: Attributes of a patient-friendly insulin and Delivery } \\
\text { Device }\end{array}$} \\
\hline \multicolumn{2}{|c|}{ Insulin } \\
\hline Attributes & Description \\
\hline $\begin{array}{l}\text { Efficacy } \\
\text { Safety } \\
\text { Tolerability } \\
\text { Convenience } \\
\text { Flexibility } \\
\end{array}$ & $\begin{array}{l}\text { Glycaemia control } \\
\text { Lack of hypoglycemia } \\
\text { No weight gain } \\
\text { Less frequent administration } \\
\text { No or minimal insulin-meal time gap }\end{array}$ \\
\hline \multicolumn{2}{|r|}{ Delivery device } \\
\hline Attributes & Description \\
\hline $\begin{array}{l}\text { Compact } \\
\text { Easy to use } \\
\text { Pain free }\end{array}$ & $\begin{array}{l}\text { Easy to carry, easy to store } \\
\text { Visual-friendly, tactile-friendly, pressure-friendly } \\
\text { Short, thin needles }\end{array}$ \\
\hline
\end{tabular}

lowering drugs with fixed doses (such as the gliptins), as compared with earlier drugs, which need (complex) dose titration in each patient.

This pattern extends to injectable therapy as well. Glucagon like peptide 1 receptor agonists such as liraglutide have limited dose titration options, which make them easier for both physician and patient. ${ }^{[6]}$ Similar to the oral FDCs, injectable fixed ratio combinations (FRCs) are now being developed. ${ }^{[7]}$

Within the field of insulin, too, recent advances seem to follow the path described earlier. Newer insulins such as degludec are both patient-friendly and physician-helpful. The flexibility of taking an injection at any time of the day, with an inter-injection period of 8-42 hours, without regard to meal times or meal portions, provides welcome convenience to the person with diabetes. ${ }^{[8]}$ This convenience comes with efficacy as well, along with a much lower risk of hypoglycemia. These features instill a sense of confidence in the user as well as her or him family, and reduce the fears related to hypoglycemia. These benefits manifest as an improvement in quality of life, noted in analysis of various trials using degludec insulin. ${ }^{\left[{ }^{[]}\right.}$The physician finds it easier to explain insulin technique to patients if modern delivery devices are used and if there is no need to specify injections timings.

While psychological and social factors continue to be important, availability of newer, longer-acting inject able therapy will certainly help improve adherence to antidiabetes medication. This in turn will improve therapeutic outcome. Widespread use of convenient and effective modern insulins, using cutting edge delivery devices, coupled with understanding of the psychosocial factors, which impacts adherence, is the key to optimal management of diabetes.

\section{REFERENCES}

1. Kalra S, Chawla R, Madhu SV. The dirty dozen of diabetes. Indian J Endocrinol Metab 2013;17:367-9.

2. Sharma SK, Seshiah V, Sahay BK, Das AK, Rao PV, Shah S, et al. Baseline characteristics of the IMPROVE control study population: A study to evaluate the effectiveness of a standardized healthcare professionals training program. Indian J Endocrinol Metab 2012;16:471-3.

3. Mohan V, Seshiah V, Sahay BK, Shah SN, Rao PV, Banerjee S, et al. Current status of management of diabetes and glycaemic control in India: Preliminary results from the DiabCare India 2011 study. Diabetes 2012;61:A645-77.

4. Kalra S, Unnikrishnan AG, Skovlund SE. Patient empowerment in endocrinology. Indian J Endocrinol Metab 2012;16:1-3

5. Kalra S, Sahay BK, Rao MS. Fixed dose combinations in diabetes: Indian innovation, Indian pride. Indian J Endocrinol Metab 2012;16:4-5.

6. Gupta V. Glucagon-like peptide-1 analogues: An overview. Indian J Endocrinol Metab 2013;17:413-21.

7. Baruah MP, Kalra S. The novel use of GLP-1 analogue and insulin combination in Type 2 diabetes mellitus. Recent Pat Endocr Metab Immune Drug Discov 2012;6:129-35.

8. Kalra S, Unnikrishnan AG, Baruah M, Kalra B. Degludec insulin: A novel basal insulin. Indian J Endocrinol Metab 2011;15:12-6.

9. Madhu SV, Velmurugan M. Future of newer basal insulin. Indian J Endocrinol Metab 2013;17:249-53.

How to cite this article: Kalra S, Unnikrishnan AG, Das AK. Improving adherence to insulin: Hope with degludec. J Soc Health Diabetes 2014;2:1-2.

Source of Support: Nil. Conflict of Interest: None declared. 